\title{
Effective Approach to Detection of Password File Using Honeywords
}

\author{
Dipali Dhumal ${ }^{1}$, Shyam Gupta ${ }^{2}$ \\ ${ }^{1}$ PG Student, Siddhant College of Engineering, Sudumbre, Savitribai Phule Pune University \\ ${ }^{2}$ Professor, Computer Department, Siddhant College of Engineering, Sudumbre, Savitribai Phule Pune University
}

\begin{abstract}
Today"s technical world has improved a lot, but there are many security related issues. One of them is password files. password files has got a lot of security problem that has affected millions of users as well as many companies. password file is generally stored in encrypt format, if a password file is stolen or theft by using the password cracking techniques and decryption technique it is easy to capture most of the plaintext and encrypt passwords. For troubleshoot this here we create the honeyword password, i.e. a False password using a perfectly flat honeyword generation method, and try to attract illegal or unauthorized user. Hence that time we detect the unauthorized user. Here we also protect the original data from unauthorized user. As mentioned above, in this project we have used Honeywords also called as Sweet Password Security Strategy.
\end{abstract}

Keywords: Honeywords, Honeypot, Login, OTP, Authentication, Password cracking, Passwords, Decoy, Documents

\section{Introduction}

Generally in many companies and software industries store their data in databases like ORACLE or Mysql or may be other. So,the entry point of a system which is required user name and password are stored in encrypt form in database. Once a password file is stolen, by using the password cracking technique it is easy to capture most of the plaintext passwords. So for avoiding it, there are two issues that should be considered to overcome these security problems: first passwords must be protected and secure by using the appropriate algorithm. And the second point is that a secure system should detect the entry of unauthorized user in the System. In the proposed system we focus on the Honeywords i.e. fake passwords and accounts. The

administrator purposely creates user accounts and detects a password disclosure, if any one of the honeypot passwords get used it is easily to detect the admin. According to the study, for each user incorrect login attempts with some passwords lead to Honeypot accounts, i.e. malicious behavior is recognized. In proposed system, We create the password in plane text,and stored it with the fake password set. We analyze the honeyword approach and give some remarks about the security of the system. When unauthorized user attempts to enter the system and get access the database, the alarm is triggered and gets notification to the administrator, since that time unauthorized user get decoy documents. i.e. Fake database.

\section{Literature Survey}

\begin{tabular}{|c|c|c|c|c|c|c|c|c|}
\hline $\begin{array}{c}S . \\
\text { No }\end{array}$ & Title & $\begin{array}{l}\text { Name of } \\
\text { author }\end{array}$ & Year & Publisher name & Techniques used & Advantages & Disadvantages & remarks \\
\hline 1 & $\begin{array}{l}\text { Understanc } \\
\text { ing } \\
\text { Password } \\
\text { Database } \\
\text { Compromi } \\
\text { ses }\end{array}$ & $\begin{array}{l}\text { D.Mirante and } \\
\text { C. Justin }\end{array}$ & 2013 & \begin{tabular}{|c|} 
Department of \\
Compute $r$ \\
Science and \\
Engineer ing \\
Polytech nic \\
Institute of NYU
\end{tabular} & $\begin{array}{l}\text { It forces the attacker } \\
\text { to brute force the } \\
\text { hashes one at a time, } \\
\text { instead of attacking } \\
\text { them as a group }\end{array}$ & \begin{tabular}{|} 
offering the benefit of \\
flexibility, with the \\
ability to provide \\
resources almost \\
instantaneously as \\
necessary to avoid site \\
shutdown
\end{tabular} & \begin{tabular}{|} 
high profile \\
website \\
intrusions, \\
wherein user \\
login \\
credentials and \\
other data were \\
compromised
\end{tabular} & $\begin{array}{c}\text { A study was } \\
\text { undertaken to } \\
\text { research } \\
\text { information posted } \\
\text { on the web } \\
\text { concerning recent, } \\
\text { high profile website } \\
\text { intrusions }\end{array}$ \\
\hline 2 & $\begin{array}{l}\text { If Your } \\
\text { Password } \\
\text { is } 123456, \\
\text { Just Make } \\
\text { It Hackme }\end{array}$ & $\begin{array}{c}\text { The Dangers } \\
\text { of Weak } \\
\text { Hashes }\end{array}$ & 2013 & $\begin{array}{l}\text { SANS Institute } \\
\text { InfoSec } \\
\text { Reading Room, } \\
\text { Tech. Rep., } \\
2013\end{array}$ & $\begin{array}{l}\text { basics of password } \\
\text { hashing, look at } \\
\text { password cracking } \\
\text { software and } \\
\text { hardware, and } \\
\text { discuss best } \\
\text { practices for using } \\
\text { hashes securely }\end{array}$ & $\begin{array}{c}\text { hashes are } \\
\text { compromised it is not } \\
\text { easy for hackers to } \\
\text { generate passwords } \\
\text { from the hashes }\end{array}$ & \begin{tabular}{|} 
Password \\
leaks are \\
becoming a \\
common \\
occurrence on \\
the internet \\
with several \\
large scale \\
leaks happing \\
every year
\end{tabular} & $\begin{array}{l}\text { Don }{ }^{e e} \text { try to } \\
\text { create your own } \\
\text { hashing } \\
\text { algorithm } \\
\text { Don }{ }^{c e} \text { t use } \\
\text { outdated } \\
\text { algorithms } \\
\text { (such as MD5 } \\
\text { or SHA1) } \\
\text { Use SHA2 or } \\
\text { similar strength } \\
\text { algorithm }\end{array}$ \\
\hline
\end{tabular}


International Journal of Science and Research (IJSR)

ISSN (Online): 2319-7064

Index Copernicus Value (2013): 6.14 | Impact Factor (2014): 5.611

\begin{tabular}{|c|c|c|c|c|c|c|c|c|}
\hline 3 & $\begin{array}{l}\text { M. Weir, } \\
\text { S. } \\
\text { Aggarwal, } \\
\text { B. de } \\
\text { Medeiros, } \\
\text { and B. } \\
\text { Glodek }\end{array}$ & \begin{tabular}{|c} 
Password \\
Cracking \\
Using \\
Probabili stic \\
Context- \\
Free \\
Grammar s
\end{tabular} & 2009 & $\begin{array}{c}\text { Password } \\
\text { Cracking Using } \\
\text { Probabili stic } \\
\text { Context- Free } \\
\text { Grammar s," in } \\
\text { Security and } \\
\text { Privacy,30th } \\
\text { IEEE Symposi } \\
\text { um on. } \\
\text { IEEE,2009, }\end{array}$ & $\begin{array}{l}\text { This grammar allows } \\
\text { us to generate word- } \\
\text { mangling rules, and } \\
\text { from them, password } \\
\text { guesses to be used in } \\
\text { password cracking }\end{array}$ & $\begin{array}{l}\text { This approach seems } \\
\text { to provide a more } \\
\text { effective way to crack } \\
\text { passwords as } \\
\text { compared to } \\
\text { traditional methods }\end{array}$ & $\begin{array}{c}\text { approach was } \\
\text { able to crack } \\
28 \%\end{array}$ & $\begin{array}{l}\text { our approach was } \\
\text { able to crack } 28 \% \\
\text { to } 129 \% \text { more } \\
\text { passwords than } \\
\text { John the Ripper, a } \\
\text { publicly available } \\
\text { standard password } \\
\text { cracking program. }\end{array}$ \\
\hline 4 & F. Cohen & $\begin{array}{l}\text { The Use of } \\
\text { Deception } \\
\text { Techniques: } \\
\text { Honeypots } \\
\text { and Decoys }\end{array}$ & 2006 & \begin{tabular}{|} 
Handboo k of \\
Informati on \\
Security, vol. 3, \\
pp. 646-655, \\
2006
\end{tabular} & $\begin{array}{l}\text { deception technique } \mathrm{s} \\
\text { have the demons } \mathrm{t} \\
\text { rated ability to } \\
\text { increase attacker } \\
\text { workload and reduce } \\
\text { attacker effectiveness }\end{array}$ & $\begin{array}{l}\text { The most critical work } \\
\text { that must be done in } \\
\text { order to make } \\
\text { progress is the } \\
\text { systematic study of } \\
\text { the effectivenes s of } \\
\text { deception techniques } \\
\text { against combined } \\
\text { systems with people } \\
\text { and computers. }\end{array}$ & \begin{tabular}{|} 
Modern \\
defensive \\
computer \\
deceptions are \\
in their \\
infancy, but \\
they are \\
moderately \\
effective, even \\
in this \\
simplistic state
\end{tabular} & $\begin{array}{c}\text { This article has } \\
\text { summarized a } \\
\text { great deal of } \\
\text { information on the } \\
\text { history of } \\
\text { honeypot s and } \\
\text { decoys for use in } \\
\text { defense of } \\
\text { computer systems. }\end{array}$ \\
\hline 5 & $\begin{array}{l}\text { M.H. } \\
\text { Almeshek } \\
\text { ah , E. H. } \\
\text { Spafford, } \\
\text { and M. J. } \\
\text { Atallah }\end{array}$ & \begin{tabular}{|c} 
Improving \\
Security using \\
Deception,
\end{tabular} & 2013 & $\begin{array}{c}\text { Center for } \\
\text { Education and } \\
\text { Research } \\
\text { Informati on } \\
\text { Assuranc e and } \\
\text { Security, } \\
\text { Purdue } \\
\text { Universit y, } \\
\text { Tech. Rep. } \\
\text { CERIAS Tech } \\
\text { Report 2013-13, } \\
2013\end{array}$ & $\begin{array}{c}\text { We explore complex } \\
\text { relationships among } \\
\text { protection } \\
\text { techniques ranging } \\
\text { from denial and } \\
\text { isolation, to } \\
\text { degradation and } \\
\text { obfuscation, through } \\
\text { negative information } \\
\text { and deception, } \\
\text { ending with } \\
\text { adversary attribution } \\
\text { and counter- } \\
\text { operations. }\end{array}$ & $\begin{array}{c}\text { outlined a new } \\
\text { classification scheme } \\
\text { for deception } \\
\text { techniques in cyber } \\
\text { security }\end{array}$ & $\begin{array}{l}\text { have shown } \\
\text { how some of } \\
\text { these } \\
\text { techniques } \\
\text { have been } \\
\text { known and } \\
\text { used for many } \\
\text { years, but that } \\
\text { the field is } \\
\text { under- } \\
\text { developed }\end{array}$ & $\begin{array}{l}\text { explained how } \\
\text { systems can be } \\
\text { augmented to use } \\
\text { deception and } \\
\text { false information } \\
\text { to protect them } \\
\text { and their data, to } \\
\text { degrade attacks, to } \\
\text { expose attackers, } \\
\text { to enhance } \\
\text { attribution, and } \\
\text { possibly to be used } \\
\text { to damage or } \\
\text { degrade attacker } \\
\text { capabilities. }\end{array}$ \\
\hline 6 & $\begin{array}{l}\text { C. Herley } \\
\text { and D. } \\
\text { Florencio }\end{array}$ & $\begin{array}{l}\text { Protecting } \\
\text { financial } \\
\text { institutio ns } \\
\text { from brute- } \\
\text { force attacks }\end{array}$ & 2008 & \begin{tabular}{|c|} 
Microsoft \\
Research One \\
Microsoft Way \\
Redmond, WA
\end{tabular} & $\begin{array}{c}\text { show that is simple } \\
\text { to ensure that a } \\
\text { brute-force attacker } \\
\text { will encounter } \\
\text { hundreds or even } \\
\text { thousands of } \\
\text { honeypot accounts } \\
\text { for every real break- } \\
\text { in. }\end{array}$ & $\begin{array}{l}\text { activity in the } \\
\text { honeypots provides } \\
\text { the data by which the } \\
\text { bank learns the } \\
\text { attackers attempts to } \\
\text { tell real from honeypot } \\
\text { accounts, and his cash } \\
\text { out strategy. }\end{array}$ & $\begin{array}{l}\text { examine the } \\
\text { problem of } \\
\text { protecting } \\
\text { online banking } \\
\text { accounts from } \\
\text { password } \\
\text { brute-forcing } \\
\text { attacks. }\end{array}$ & $\begin{array}{l}\text { In a brute-force } \\
\text { attack repeated } \\
\text { credential pairs are } \\
\text { tried in an attempt } \\
\text { to gain access to an } \\
\text { account. The } \\
\text { simplest is directed } \\
\text { against a single } \\
\text { account: the } \\
\text { attacker tries all } \\
\text { possible passwords } \\
\text { for one userID } \\
\text { until one succeeds. }\end{array}$ \\
\hline 7 & \begin{tabular}{|c} 
H. \\
Bojinov, \\
E. \\
Bursztein, \\
X. Boyen, \\
and D. \\
Boneh
\end{tabular} & $\begin{array}{l}\text { Kamouflage: } \\
\text { Loss- } \\
\text { resistant } \\
\text { Password } \\
\text { Manage ment }\end{array}$ & 2008 & $\begin{array}{c}\text { Computer } \\
\text { Security- } \\
\text { ESORIC S } \\
\text { 2010. Springer, } \\
\text { 2010, pp. 286- } \\
\text { 302 }\end{array}$ & $\begin{array}{l}\text { Introduce Kamouage: } \\
\text { a new architecture for } \\
\text { building the ft- } \\
\text { resistant password } \\
\text { managers. An } \\
\text { attacker who steals a } \\
\text { laptop or cell phone } \\
\text { with a Kamouage- } \\
\text { based password } \\
\text { manager is forced to } \\
\text { carry out a } \\
\text { considerable amount } \\
\text { of online work before } \\
\text { obtaining any user } \\
\text { credentials. }\end{array}$ & $\begin{array}{l}\text { replacement for the } \\
\text { built-in Firefox } \\
\text { password manager, } \\
\text { and provide } \\
\text { performance } \\
\text { measurements and the } \\
\text { results from } \\
\text { experiments with } \\
\text { large real- world } \\
\text { password sets to } \\
\text { evaluate the feasibility } \\
\text { and effectiveness of } \\
\text { our approach }\end{array}$ & \begin{tabular}{|} 
presented a \\
system to \\
secure the \\
password \\
database on a \\
mobile device \\
from attacks \\
that are often \\
ignored by \\
deployed \\
password \\
managers.
\end{tabular} & $\begin{array}{c}\text { Kamouage is well } \\
\text { suited to become a } \\
\text { standard } \\
\text { architecture for } \\
\text { password } \\
\text { managers on mo- }\end{array}$ \\
\hline
\end{tabular}




\section{International Journal of Science and Research (IJSR) \\ ISSN (Online): 2319-7064}

Index Copernicus Value (2013): 6.14 | Impact Factor (2014): 5.611

\section{Purpose and Scope}

- The main aim of project is to validating whether data access is authorized or not when abnormal information access is detected.

- Confusing the attacker with fake information.

- This protects against the misuse of the user"s real data.

- We propose a completely different approach to securing the cloud using decoy information technology, that we have come to call fog computing.

- We use this technology to launch disinformation attacks against malicious insiders, preventing them from distinguishing the real sensitive customer data from fake worthless data.

\section{Project Objective}

The proposal is for "Making Data Inconspicuous In system " based applications for the purpose to avoid the attack of Insider on confidential and important data. We propose a simple method for improving the security of hashed passwords. the maintenance of additional "honeywords" (false passwords) associated with each user"e account. An adversary who steals a file of hashed passwords and inverts the hash function cannot tell if he has found the password or a honeyword. The attempted use of a honeyword for login sets off an alarm. An auxiliary server (the "honeychecker") can distinguish the user password from honeywords for the login routine, and will set off an alarm if a honeyword is submitted.

\section{Mathematical Model}

Considering that we have database „, $\mathrm{D}^{\mathrm{ce}}$ and „n $\mathrm{n}^{\mathrm{ce}}$ number of attribute such as user name, user id etc. $\mathrm{D}=\{\mathrm{A} \mid \mathrm{A} \varepsilon$ Information of user $\}$

Here D is the set of all A such that A is information of user which is to be store on server

Consider following function STORE (D, SERVER):

- Here admin enters the user information into database at server.

Let us consider that the receiver provide us with value " $\mathrm{X}$ " for every input it obtain from the every time login account of the particular user .so we can further assume to have a set ,s to have value " $n$ " number of detect value at particular instance. Let us denote the current situation in the following manner

\section{$\mathrm{S}=\{\mathrm{X} \mid \square \mathrm{X} \varepsilon \mathrm{D} \exists$ ID for attacker $\}$}

Here $\mathrm{S}$ is the set all $\mathrm{X}$ such that for all $\mathrm{X}$ there exits Id for user.

- Now, for some $X$ value that match with some value inside the database when admin check user account update.

1) GET(D,X,SERVER): Admin get all information about the user account from server.

2) PUT(X,ATK,SERVER): Here admin will upload attacker"s information on server.

3) PUTP(X,REPORT,SERVER) : Here admin upload daily report on server.

\section{Conclusion and Future Scope}

We present a standard approach to securing personal and business data in the system. We propose monitoring data access patterns by profiling user behavior to determine if and when a malicious insider illegally accesses someone ${ }^{\text {ee }}$ s documents in a system service. Decoy documents stored in the system alongside the user"s real data also serve as sensors to detect illegitimate access. Once unauthorized data access or exposure is suspected, and later verified, with challenge questions for instance, we inundate the malicious insider with fake information in order to dilute or divert useres real data. Such preventive attacks that rely on disinformation technology could provide unprecedented levels of security in the system and in social networks model. In the future, we would like to refine our model by involving hybrid generation algorithms to also make the total hash inversion process harder for an adversary in getting the passwords in plaintext form leaked password hash file. Hence, by developing such methods both of two security objectives - increasing the total effort in recovering plaintext passwords from the hashed lists and detecting the password disclosure - can be provided at the same time.

\section{References}

[1] D. Mirante and C. Justin, "Understanding Password Database Compromises," Dept. of Computer Science and Engineering Polytechnic Inst. of NYU, Tech. Rep. TR-CSE-2013-02, 2013.

[2] A. Vance, "If Your Password is 123456, Just Make It Hackme," The New York Times, vol. 20, 2010

[3] K. Brown, "The Dangers of Weak Hashes," SANS Institute InfoSec Reading Room, Tech. Rep., 2013.

[4] M. Weir, S. Aggarwal, B. de Medeiros, and B. Glodek, "Password Cracking Using Probabilistic Context-Free Grammars," in Security and Privacy, 30th IEEE Symposium on. IEEE, 2009, pp. 391-405.

[5] F. Cohen, "The Use of Deception Techniques: Honeypots and Decoys," Handbook of Information Security, vol. 3, pp. 646-655, 2006.

[6] M. H. Almeshekah, E. H. Spafford, and M. J. Atallah, "Improving Security using Deception," Center for Education and Research Information Assurance and Security, Purdue University, Tech. Rep. CERIAS Tech Report 2013-13, 2013.

[7] C. Herley and D. Florencio, "Protecting financial institutions from brute-force attacks," in SEC 08 , 2008, pp. 681-685.

[8] H. Bojinov, E. Bursztein, X. Boyen, and D. Boneh, "Kamouflage: Loss-resistant Password Management," in Computer Security-ESORICS 2010. Springer, 2010, pp. 286-302.

[9] A. Juels and R. L. Rivest, "Honeywords: Making Passwordcracking Detectable," in Proceedings of the 2013 ACM SIGSAC Conference on Computer \& Communications Security, ser. CCS "13. New York, NY, USA: ACM, 2013, pp. 145-160. [Online]. Available: http://doi.acm.org/10.1145/2508859.2516671

[10]M. Burnett, "The Pathetic Reality of Adobe Password Hints," https://xato.net/windows- security/adobepassword-hints.

\section{Volume 4 Issue 12, December 2015}

